\title{
KADAR VITAMIN C JERUK SUNKIST PERAS DAN INFUSED WATER
}

\author{
Haitami, Annisa Ulfa, Akhmad Muntaha \\ Jurusan Analis Kesehatan Poltekkes Kemenkes Banjarmasin \\ JI Mistar Cokrokusumo 4a Banjarbaru \\ e-mail: haitami4@yahoo.co.id
}

\begin{abstract}
Orange is one of the fruits that are widely consumed by the society, besides to the sweet taste and attractive appearance orange also has various benefits for the body such as vitamins and minerals. The famous and much-favored orange is a beneficial Sunkist orange can treat fever, treat infections, improve body immunity and decreasing the number of cholesterol. There are several ways of processing oranges such as orange juice and infused the water. The purpose of this study is to know the ratio of vitamin C content in the juice of Sunkist with infused water orange Sunkist. Types of research is analytic survey with comparative study approach. The research sample used was orange Sunkist which made two treatment that is the juice of Sunkist orange and infused water by using lodimetry titration method. The results of the average vitamin C content in 10 samples of citrus Sunkist for 348,82 ppm and the average vitamin $C$ level in 10 samples infused water of orange Sunkist equal to $67,59 \mathrm{ppm}$. Based on statistical test result using Independent Sample T-Test test stated that there is the difference of vitamin $\mathrm{C}$ content on freshly squeezed orange Sunkist with infused water of orange Sunkist with the value of significance 0.000 . Suggested for further researcher can do research of vitamin C Infused water level by combining with other fruit
\end{abstract}

Keywords: vitamin C; sunkist orange

Abstrak: Jeruk adalah salah satu buah-buahan yang banyak dikonsumsi oleh masyarakat, selain rasanya yang manis dan tampilannya menarik juga memiliki berbagai macam manfaat bagi tubuh seperti vitamin dan mineral. Jeruk yang terkenal dan banyak disukai adalah jeruk sunkist yang bermanfaat dapat mengobati demam, mengobati infeksi, meningkatkan imunitas tubuh dan menurunkan kolesterol. Ada beberapa cara pengolahan jeruk tersebut seperti jeruk peras dan infused water. Tujuan penelitian ini yaitu mengetahui perbandingan kadar vitamin $\mathrm{C}$ pada perasan jeruk sunkist dengan infused water jeruk sunkist. Jenis penelitian survey analitik dengan pendekatan comparative study. Sampel penelitian yang digunakan adalah jeruk sunkist yang dibuat dua perlakuan yaitu perasan jeruk sunkist dan infused water dengan menggunakan metode titrasi lodimetri. Hasil penelitian rata-rata kadar vitamin $\mathrm{C}$ pada 10 sampel perasan jeruk sunkist sebesar $348,82 \mathrm{ppm}$ dan rata-rata kadar vitamin $C$ pada 10 sampel infused water jeruk sunkist sebesar 67,59 ppm. Berdasarkan hasil uji statistik dengan menggunakan uji Independent Sample T-Test menyatakan bahwa ada perbedaan kadar vitamin C pada perasan jeruk sunkist dengan infused water jeruk sunkist dengan nilai signifikansi 0,000 . Disarankan untuk peneliti selanjutnya dapat melakukan penelitian kadar vitamin $\mathrm{C}$ Infused water dengan mengkombinasikan dengan buah yang lain.

Kata kunci: vitamin C; jeruk sunkist 


\section{PENDAHULUAN}

Jeruk adalah salah satu buah-buahan yang banyak dikonsumsi oleh masyarakat, selain rasanya yang manis dan tampilannya menarik juga memiliki berbagai macam manfaat bagi tubuh. Selain kaya vitamin dan mineral, jeruk juga mengandung serat makanan yang esensial (sangat dibutuhkan tetapi tidak dapat dibuat oleh tubuh) berguna bagi pertumbuhan dan perkembangan tubuh manusia. Jeruk yang terkenal dan banyak disukai oleh orang-orang adalah jeruk navel atau yang lebih dikenal orang adalah jeruk sunkist. Jeruk jenis ini bisa didapatkan dengan mudah dimanapun, baik itu di pasar tradisional, pinggir jalan, supermarket ataupun gerai buah. Kelebihan lain dari buah ini adalah dia tidak memiliki musim alias selalu tersedia sepanjang tahun. Jeruk ini juga berbeda dari jeruk lainnya, karena kulitnya agak keras sehingga lebih sulit untuk dibuka dan jeruk jenis ini tahan lama dalam penyimpanannya (Naharsari, 2007).

Adapun manfaat jeruk sunkist untuk kesehatan adalah untuk mengobati demam, mengobati infeksi, meningkatkan imunitas tubuh, menurunkan kolesterol, dan juga membuat limpa lebih kuat. Dengan berbagai manfaat jeruk sunkist ini, maka sangat disarankan untuk mengkonsumsinya. Ada berbagai cara untuk mengkonsumsi jeruk ini, yaitu langsung dimakan, dibuat jus, ataupun dibuat puding. Belakangan ini, teknik mengkonsumsi buah sudah semakin berkembang salah satu tren yang sedang digemari yaitu Infused Water.

Infused Water atau dikenal pula dengan spa water adalah air putih yang diberi tambahan potongan buah-buahan kemudian didiamkan beberapa jam sampai sari buahnya keluar, dapat didiamkan dalam lemari es selama 4 - 12 jam, lalu siap dikonsumsi, sehingga memberikan cita rasa dan manfaat untuk kesehatan. Dengan cara ini, air putih yang dikonsumsi menjadi lebih beraroma dan terasa segar. Namun demikian, bukan berarti infused water akan terasa manis seperti jus atau sari buah, sebab pembuatan infused water tanpa gula maupun zat aditif lainnya. Dan inilah yang menjadi keunggulan infused water yang berbeda dengan air minum biasa, karena infused water merupakan air putih beraroma secara alami.

Infused water bisa juga digunakan untuk mereka yang tidak sempat mengonsumsi buah atau kurang suka buah. Dengan memasukkan irisan buah yang berwarna-warni dapat memancing selera seseorang untuk menyukai buah. Infused water bisa menjadi alternatif untuk mendorong orang minum air putih lebih banyak (Soraya, 2014).

Manusia membutuhkan zat gizi yang beraneka ragam, tetapi yang dibutuhkan dalam jumlah besar adalah karbohidrat, protein, dan lemak. Tubuh juga membutuhkan zat gizi yang mempunyai peranan penting bagi fungsi sel tubuh, misalnya vitamin C (Muchtadi, 2009).

Vitamin adalah komponen tambahan makanan yang berperan sangat penting dalam gizi manusia. Vitamin pada umumnya dapat dikelompokkan dalam dua kelompok yaitu vitamin yang larut dalam lemak yakni vitamin $A, D, E$, dan vitamin yang larut dalam air seperti vitamin B dan vitamin C. (Rohman dan Sumantri, 2007).

Vitamin $\mathrm{C}$ adalah salah satu jenis vitamin yang larut dalam air dan memiliki peranan penting dalam menangkal berbagai penyakit. Kebutuhan vitamin $\mathrm{C}$ dalam tubuh didapatkan dari bahan makanan seperti sayur-sayuran dan buah-buahan. Kandungan vitamin C pada jeruk sunkist bermanfaat untuk menurunkan resiko terkena serangan kanker usus besar, hal ini dikarenakan jeruk bisa membantu mengusir radikal bebas yang dapat menyebabkan kerusakan DNA. Vitamin C juga memiliki fungsi sebagai sistem kekebalan tubuh, misalnya untuk menangkal flu dan mencegah infeksi pada telinga. (Puspaningtyas, 2013). Vitamin C juga terbukti dapat memelihara kehamilan mencit diabetes dibandingkan dengan kontrol positif (Arifin dkk, 2007)

Apabila tubuh kekurangan vitamin C maka akan mengakibatkan anemia, kulit kering, pendarahan internal yang terjadi pada bagian mata, radang gusi, menurunnya sistem imun, sulit menyembuhkan luka, nyeri otot, dan mudah memar. Namun apabila tubuh kelebihan vitamin $C$ dapat berbahaya bagi kesehatan tubuh, seperti fungsi penyerapan vitamin B12 yang terganggu, produksi asam lambung meningkat, meningkatnya kadar asam urat di dalam kantung kemih, menyebabkan gangguan dan kerusakan pada otak, dan menyebabkan alergi serta iritasi pada bagian kulit (Youngson, 2005). Tujuan penelitian ini adalah untuk mengetahui perbandingan kadar vitamin $\mathrm{C}$ pada perasan jeruk sunkist dengan infused water jeruk sunkist. 


\section{BAHAN DAN METODE}

Metode yang digunakan dalam penelitian adalah survey analitik dengan pendekatan comparative study (studi perbandingan), yaitu suatu metode perbandingan dengan cara membandingkan fakta yang diperoleh dari 2 kelompok sampel atau lebih (Notoadmojo, 2010). Sampel yang digunakan dalam penelitian adalah Jeruk Sunkist. Variabel terikat pada penelitian ini adalah kadar vitamin $\mathrm{C}$ yang diperiksa dengan metode lodimetri dengan satuan ppm. Variabel bebas pada penelitian ini adalah pengolahan jeruk sunkist. Pembuatan sampel jeruk dengan dua cara yaitu Infused water dan perasan Jeruk Sunkist.

Pembuatan Infused water dengan cara jeruk sunkist yang akan digunakan dicuci dengan air mengalir. Khusus untuk jeruk, gosok seluruh permukaan kulitnya dengan air garam untuk menghilangkan rasa pahit. Potong-potong jeruk sunkist yang akan digunakan. Masukkan potongan jeruk sunkist ke dalam gelas kaca bersih yang ada tutupnya. Tuangkan aquadest dengan perbandingan $200 \mathrm{~mL}$ untuk duabelas potong buah dalam satu jeruk sunkist. Masukkan kedalam lemari es, diamkan sekitar 4 jam, agar sari buah keluar dan larut dalam air. Setelah itu dapat dikeluarkan dari lemari es dan tutup rapat (Puspaningtyas D.E \& Prasetyaningrum Y.I, 2014)

Pembuatan Perasan Jeruk Sunkist dengan mencuci jeruk sunkist yang akan digunakan. Belah 2 bagian buah jeruk sunkist. Peras jeruk sunkist dengan menggunakan alat perasan. Siapkan gelas dengan saringan, tuangkan air perasan jeruk sunkist kedalam labu ukur $100 \mathrm{~mL}$ dan di add dengan aquadest sampai tanda batas.

Penetapan kadar vitamin $\mathrm{C}$ dengan terlebih dahulu Standarisasi larutan $\mathrm{Na}_{2} \mathrm{~S}_{2} \mathrm{O}_{3}$ $0,01 \mathrm{~N}$ dengan larutan $\mathrm{KBrO}_{3} 0,01 \mathrm{~N}$, yaitu dengan memipet $10,0 \mathrm{~mL}$ larutan $\mathrm{KBrO}_{3} 0,01$ $\mathrm{N}$ kedalam erlenmeyer. Menambahkan \pm 100 $\mathrm{mL}$ aquadest. Menambahkan $5,0 \mathrm{~mL} \mathrm{H}_{2} \mathrm{SO}_{4}$ $0,01 \mathrm{~N}$ dan $10,0 \mathrm{~mL}$ larutan $\mathrm{KI} 10 \%$, ditutup. Menitrasi dengan larutan $\mathrm{Na}_{2} \mathrm{~S}_{2} \mathrm{O}_{3} \quad 0,01 \mathrm{~N}$ sampai kuning muda. Menambahkan $1 \mathrm{~mL}$ amilum $1 \%$ sampai warna biru. Menitrasi dilanjutkan dengan larutan $\mathrm{Na}_{2} \mathrm{~S}_{2} \mathrm{O}_{3} \quad 0,01 \mathrm{~N}$ sampai warna biru tepat hilang.

Standarisasi larutan iodium $0,01 \mathrm{~N}$ dengan larutan $\mathrm{Na}_{2} \mathrm{~S}_{2} \mathrm{O}_{3}, 0,01 \mathrm{~N}$ dengan cara memipet larutan $\mathrm{Na}_{2} \mathrm{~S}_{2} \mathrm{O}_{3} 0,01 \mathrm{~N}$ (yang telah diketahui normalitasnya) sebanyak $10,0 \mathrm{~mL}$ kedalam erlenmeyer. Menambahkan \pm 100 $\mathrm{mL}$ aquadest dan 1,0 $\mathrm{mL} \mathrm{HCl}$. Menambahkan
$1 \mathrm{~mL}$ indikator amilum $1 \%$. Menitrasi dengan menggunakan larutan baku lodium 0,01 N sampai terbentuk warna biru.

Penetapan kadar vitamin $\mathrm{C}$, dengan cara memipet $10,0 \mathrm{~mL}$ sampel, masukkan dalam erlenmeyer. Menambahkan $1 \mathrm{~mL}$ indikator amilum 1\%. Menitrasi dengan menggunakan larutan baku lodium $0,01 \mathrm{~N}$ sampai terbentuk warna biru.

Perhitungan Rumus kadar vitamin $\mathrm{C}$ Jeruk Peras $=$

$(\mathrm{V}(\mathrm{mL}) \times \mathrm{N}($ iod $)) \times B E(88,06) \times D(100 / 10) \times 1000=\ldots . . p p m$

100

Infused Water $=$

$(V(m L) \times N($ iod $)) \times B E(88,06) \times D(200 / 20) \times 1000=\ldots . . p p m$

200

Keterangan :

$\mathrm{V}=$ Volume titrasi sampel

$\mathrm{N}=$ Normalitas lod.

$\mathrm{D}=$ Delutasi

$\mathrm{Be}=$ Bobot ekuivalen vitamin $\mathrm{C}$

\section{HASIL DAN PEMBAHASAN Karakteristik Sampel}

Sampel yang digunakan pada penelitian ini adalah jeruk sunkist. Jeruk ini berwarna orange, berbentuk bulat atau agak ovale, mempunyai ciri khas yaitu terdapat pusar (udel) di ujung buahnya, daging buah umumnya tidak berbiji, dan kulit yang keras berbeda dari jenis jeruk lainnya.

Berdasarkan hasil penelitian yang telah dilakukan terhadap kadar vitamin $\mathrm{C}$ dengan menggunakan metode lodimetri pada perasan jeruk sunkist dengan infused water jeruk sunkist didapatkan hasil seperti pada Tabel 1. dan Tabel 2.

Tabel 1. Hasil Perhitungan Penetapan Rata-rata Kadar Vitamin C pada Perasan Jeruk Sunkist.

\begin{tabular}{ccc}
\hline & \multicolumn{2}{c}{$\begin{array}{r}\text { Rata-rata Kadar Vitamin C Jeruk } \\
\text { Sunkist (ppm) }\end{array}$} \\
\cline { 2 - 3 } & Sampel & $\begin{array}{c}\text { Perasan Jeruk } \\
\text { Sunkist }\end{array}$ \\
\hline 1 & Sampel 1 & 347,8 \\
2 & Sampel 2 & 354,9 \\
3 & Sampel 3 & 347,8 \\
4 & Sampel 4 & 342,9 \\
5 & Sampel 5 & 342,9 \\
6 & Sampel 6 & 354,9 \\
7 & Sampel 7 & 349,6 \\
8 & Sampel 8 & 354,9 \\
9 & Sampel 9 & 342,9 \\
10 & Sampel 10 & 349,6 \\
\hline
\end{tabular}


Tabel 2. Hasil Perhitungan Penetapan Rata-rata Kadar Vitamin C pada Infused Water Jeruk Sunkist.

\begin{tabular}{|c|c|c|}
\hline \multirow{2}{*}{ No } & \multicolumn{2}{|c|}{$\begin{array}{c}\text { Rata-rata Kadar Vitamin C Jeruk } \\
\text { Sunkist (ppm) }\end{array}$} \\
\hline & Sampel & $\begin{array}{l}\text { Infused Water } \\
\text { Jeruk Sunkist }\end{array}$ \\
\hline 1 & Sampel 1 & 65,0 \\
\hline 2 & Sampel 2 & 70,9 \\
\hline 3 & Sampel 3 & 70,0 \\
\hline 4 & Sampel 4 & 66,6 \\
\hline 5 & Sampel 5 & 67,5 \\
\hline 6 & Sampel 6 & 65,9 \\
\hline 7 & Sampel 7 & 65,0 \\
\hline 8 & Sampel 8 & 67,5 \\
\hline 9 & Sampel 9 & 67,5 \\
\hline 10 & Sampel 10 & 70,0 \\
\hline
\end{tabular}

Berdasarkan Tabel 1. dan Tabel 2 ratarata hasil pemeriksaan kadar vitamin $C$ pada sampel perasan jeruk sunkist dengan infused water jeruk sunkist, untuk lebih jelasnya dapat dilihat pada Gambar 1. berikut:

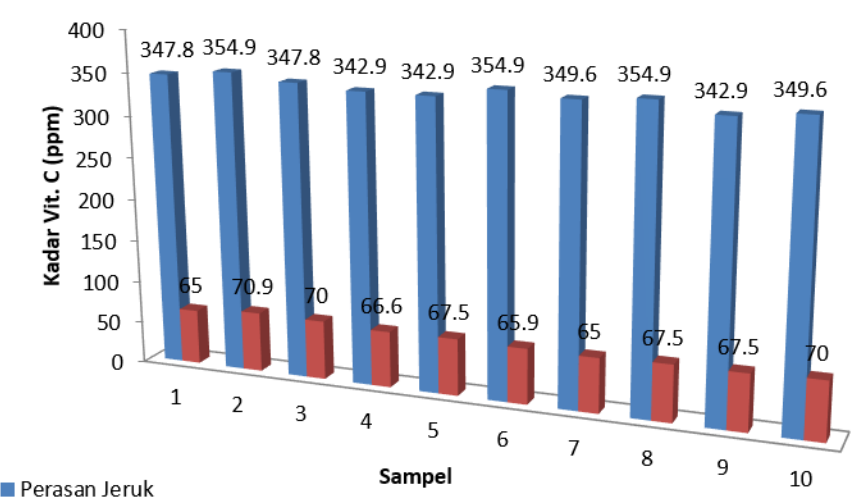

Infus Water

Gambar 1. Grafik Rata-rata Kadar Vitamin C pada Perasan Jeruk Sunkist dengan Infused Water Jeruk Sunkist

Data yang diperoleh dalam penelitian ini adalah data dengan angka mutlak. Untuk mengetahui apakah ada perbedaan kadar vitamin $C$ pada perasan jeruk sunkist dengan infused water jeruk sunkist maka digunakan uji Independent Samples T-Test.

Langkah uji statistik secara umum sebagai berikut: pada tahap awal pengujian secara statistik, dilakukan uji normalitas data (OneSamples Shapiro-Wilk Test). Uji ini berfungsi untuk mengetahui normal atau tidaknya distribusi data. Jika nilai signifikasi lebih besar dari $\alpha(\alpha=0,05)$ maka dinyatakan data berdis- tribusi normal. Sebaliknya, jika nilai signifikasi lebih kecil dari a data dinyatakan tidak berdistribusi normal dan data harus dinormalisasi maksimal dua kali. Apabila data berdistribusi normal dapat dilanjutkan dengan uji homogenitas dan uji Independent Samples TTest Jika data tidak berdistribusi normal dan tidak homogen, maka dilakukan uji non parametrik (Uji Mann Whitney).

Berdasarkan uji normalitas, uji homogenitas dan uji Independent Samples TTest dapat dilihat pada lampiran 4. Jumlah data dalam penelitian ini kurang dari 50 , oleh karena itu digunakan Shapiro Wilk untuk melihat nilai signifikasi, setelah dilakukan uji normalitas, diperoleh nilai signifikasi sebesar 0,067 . Nilai signifikasi lebih dari $\alpha(\alpha=0,05)$, artinya data berdistribusi normal. Dilanjutkan dengan uji homogenitas dan uji Independent Samples T-Test.

Hasil uji homogenitas data dapat dilihat pada kolom uji Based on Mean bahwa nilai signifikasi pada dua variabel memiliki nilai signifikasi sebesar 0,020. Nilai signifikasi kurang dari $\alpha(\alpha=0,05)$, artinya data yang dimiliki tidak homogen. Dilanjutkan dengan uji Independent Samples T-Test .

Uji Independent Samples T-Test dilakukan untuk mengetahui perbandingan kedua metode dengan tingkat kepercayaan 95\%, maka dari itu Independent Samples TTest yang digunakan yaitu jika data homogen dilihat pada kolom equal variances assumed dan jika tidak homogen dilihat pada kolom equal variances not assumed, dikatakan $\mathrm{H}_{0}$ diterima jika nilai sig (2-tailed) lebih dari $\alpha$ $(\alpha=0,05)$ dan jika nilai sig (2-tailed) kurang dari $\alpha(\alpha=0,05)$ maka dikatakan $\mathrm{H}_{0}$ ditolak.

Hasil uji Independent Samples T-Test. Dapat dilihat pada kolom uji Equal variances not assumed bahwa nilai sig (2-tailed) sebesar 0,000. Nilai signifikasi kurang dari $\alpha$ $(\alpha=0,05)$. Hal ini berarti $\mathrm{H}_{0}$ ditolak yang artinya ada perbedaan antara nilai rata-rata kadar vitamin C pada perasan jeruk sunkist dengan infused water jeruk sunkist.

Berdasarkan hasil penelitian yang telah dilakukan terhadap perbandingan kadar vitamin C pada perasan jeruk sunkist dengan infused water jeruk sunkist berdasarkan hasil uji statistik pada uji-t sampel bebas menyimpulkan bahwa terdapat perbedaan dengan angka mutlak, dimana kadar vitamin $\mathrm{C}$ pada perasan jeruk sunkist lebih besar dibandingkan dengan infused water jeruk sunkist. 
Rata-rata kadar vitamin C pada perasan jeruk sunkist untuk satu buah jeruk dengan berat \pm 230 gram kemudian dilarutkan dalam $100 \mathrm{~mL}$ aquadest didapatkan kadar vitamin C sebesar 348,82 ppm, sedangkan pada infused water satu buah jeruk dengan berat \pm 230 gram kemudian dilarutkan dalam $200 \mathrm{~mL}$ aquadest didapatkan kadar vitamin C sebanyak 67,59 ppm. Dari hasil tersebut terlihat perbedaan kadar vitamin $C$ yang cukup besar antara perasan jeruk sunkist dengan infused water jeruk sunkist. Hal itu dikarenakan pada perasan jeruk sunkist lebih pekat dan sari buah pada jeruk sunkist dipaksa keluar dengan cara diperas, sedangkan pada infused water, jeruk sunkist diolah dengan cara memotong buahnya saja dimasukkan ke dalam gelas kaca yang bertutup ditambah air lalu didiamkan selama 4 jam dalam lemari es. Vitamin $\mathrm{C}$ bersifat mudah larut dalam air. $\mathrm{Pa}-$ da infused water vitamin $C$ keluar secara perlahan-lahan sehingga vitamin $\mathrm{C}$ masih dapat tersimpan didalam daging buahnya dan sari buah yang keluar tidak sebanyak pada perasan jeruk sunkist.

Nilai gizi atau nilai vitamin C lebih rendah pada infused water tetapi berdasarkan atas hasil survey terjadi tren penggunaan infused water di dalam kehidupan sehari-hari, sehingga ini bisa menjadi pemicu agar orang yang malas mengkonsumsi air putih menjadi lebih sering mengkonsumsi air putih dengan cita rasa yang berbeda dan tentu secara tidak langsung kondisi kesehatan akan perlahan semakin membaik. Namun para ahli gizi menyarankan mengkonsumsi buah segar secara langsung justru tetap lebih baik, mengingat penyerapannya akan lebih maksimal oleh tubuh (Budiartie, 2013).

\section{KESIMPULAN}

Rata-rata kadar vitamin C pada sampel perasan jeruk sunkist sebesar 348,82 ppm. Rata-rata kadar vitamin C pada sampel infused water jeruk sunkist sebesar 67,59 ppm. Berdasarkan uji statistik menyatakan ada perbedaan kadar vitamin $\mathrm{C}$ pada perasan jeruk sunkist dengan infused water jeruk Sunkist dengan nilai signifikansi 0,000.

\section{SARAN}

Melakukan penelitian tentang kadar vitamin C Infused water dengan mengkombinasikan dengan buah yang lain.

\section{DAFTAR PUSTAKA}

Arifin, Helmi, Vivi, D., \& Almahdy, A. (2007). Pengaruh Pemberian Vitamin C terhadap
Fetus pada Mencit Diabetes. Jurnal Sains Dan Teknologi Farmasi, 12(1).

Budiartie, G. (2013). Cara Baru Minum Air Putih.

Muchtadi, D. (2009). Pengantar Ilmu Gizi. Bandung: Alfabeta.

Naharsari, N.D. (2007). Bercocok Tanam Jeruk. Semarang: Azka Press.

Notoatmodjo, S. (2010). Metodologi Penelitian Kesehatan. Jakarta: Rineka Cipta.

Puspaningtyas, D.E. (2013). The Miracle of Fruits. Jakarta: Agro Media Pustaka.

Puspaningtyas, D.E., \& Prasetyaningrum, Y.I . (2014). Variasi Favorit Infused Water Berkhasiat. Jakarta: FMedia.

Rohman, A., \& Sumantri. (2007). Analisis Makanan. Yogyakarta: Gajah Mada University Press.

Soraya, N. (2014). Infused Water. Jakarta: Penerbit Penebar Swadaya.

Youngson, R. (2005). Antioksidan: Manfaat Vitamin $C$ dan $E$ bagi Kesehatan. Jakarta: Arcan. 